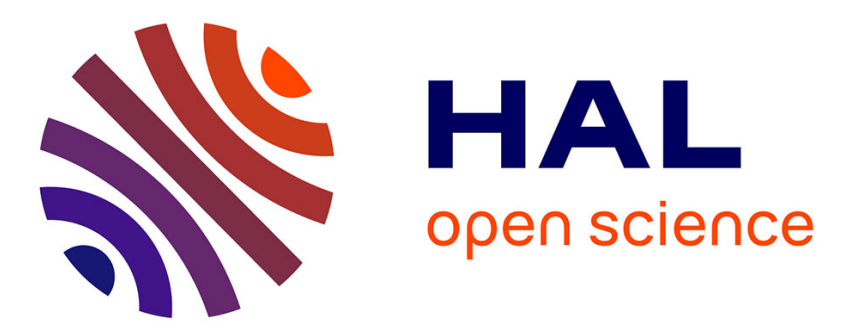

\title{
An investigation into intersex amphipods and a possible association with aquaculture
}

\author{
Alex T. Ford, Paul A. Read, Tim L. Jones, Fumiko Michino, Yvonne Pang, \\ Teresa F. Fernandes
}

\section{- To cite this version:}

Alex T. Ford, Paul A. Read, Tim L. Jones, Fumiko Michino, Yvonne Pang, et al.. An investigation into intersex amphipods and a possible association with aquaculture. Marine Environmental Research, 2007, 64 (4), pp.443. 10.1016/j.marenvres.2007.03.006 . hal-00501914

\section{HAL Id: hal-00501914 https://hal.science/hal-00501914}

Submitted on 13 Jul 2010

HAL is a multi-disciplinary open access archive for the deposit and dissemination of scientific research documents, whether they are published or not. The documents may come from teaching and research institutions in France or abroad, or from public or private research centers.
L'archive ouverte pluridisciplinaire HAL, est destinée au dépôt et à la diffusion de documents scientifiques de niveau recherche, publiés ou non, émanant des établissements d'enseignement et de recherche français ou étrangers, des laboratoires publics ou privés. 


\section{Accepted Manuscript}

An investigation into intersex amphipods and a possible association with aquaculture

Alex T. Ford, Paul A. Read, Tim L. Jones, Fumiko Michino, Yvonne Pang, Teresa F. Fernandes

PII:

S0141-1136(07)00055-4

DOI:

10.1016/j.marenvres.2007.03.006

Reference:

MERE 3114

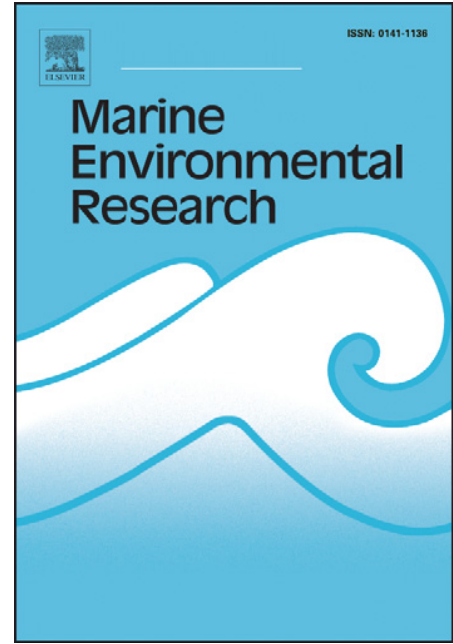

To appear in:

Marine Environmental Research

Received Date:

9 March 2006

Revised Date:

20 March 2007

Accepted Date:

21 March 2007

Please cite this article as: Ford, A.T., Read, P.A., Jones, T.L., Michino, F., Pang, Y., Fernandes, T.F., An investigation into intersex amphipods and a possible association with aquaculture, Marine Environmental Research (2007), doi: 10.1016/j.marenvres.2007.03.006

This is a PDF file of an unedited manuscript that has been accepted for publication. As a service to our customers we are providing this early version of the manuscript. The manuscript will undergo copyediting, typesetting, and review of the resulting proof before it is published in its final form. Please note that during the production process errors may be discovered which could affect the content, and all legal disclaimers that apply to the journal pertain. 


\section{ACCEPTED MANUSCRIPT}

\section{An investigation into intersex amphipods and a possible association with}

aquaculture

Alex T. Ford ${ }^{\mathrm{a}^{*}}$, Paul A. Read ${ }^{\mathrm{b}}$, Tim L. Jones ${ }^{\mathrm{c}}$, Fumiko Michino ${ }^{\mathrm{b}}$, Yvonne Pang $^{\mathrm{b}}$, Teresa F. Fernandes ${ }^{\mathrm{b}}$.

${ }^{a}$ Environmental Research Institute, North Highland College, UHI Millennium Institute, Castle Street, Thurso, Caithness, Scotland, UK, KW14 57JD.

${ }^{\mathrm{b}}$ School of Life Sciences, Napier University, 10 Colinton Road, Edinburgh, UK, EH10 5DT.

${ }^{\mathrm{b}}$ School of Biological Sciences, University of Aberdeen, Aberdeen, AB24 2TZ.

* Corresponding author. Tel.:+44-1847-889593; fax:+44-131-890014.

E-mail address: alex.ford@ thurso.uhi.ac.uk

\section{$\underline{\text { Abstract }}$}

The amphipod, Echinogammarus marinus, is common in sheltered coastal inlets, such as estuaries and sea lochs, in Scotland and exhibits increased levels of intersex in some contaminated areas. Sea lochs are commonly the location for coastal aquaculture development, and some chemicals used in fish-farming are specifically designed to target the crustacean nervous system. Therefore it was hypothesised that these chemicals may also affect neuro-endocrine pathways, causing morphological and reproductive abnormalities in non-target Crustacea. Based upon this hypothesis, Echinogammarus marinus amphipods from two different Scottish sea lochs containing salmon farms were investigated. Morphology, intersexuality, and the incidence of microsporidian parasites were recorded at sites close and at distance from fish-farms. Results suggest a higher incidence of intersexuality at sites within sea lochs, comparable to that observed in industrially contaminated sites elsewhere in Scotland. The data suggest that fish farming activity may influence the observed distributions of intersexuality within lochs. Intersex specimens were more likely to be 
infected by microsporidian parasites than non-intersex specimens. Normal females were found more likely to be infected by microsporidian parasites at sites associated with high intersexuality, suggesting the parasite as the probable feminiser. The cause(s) for the observed patterns of intersexuality are unclear, although suggestions relating to discharges from fish farms are discussed.

Keywords: Pollution, Microsporidia, Intersexuality, Crustacea, Amphipoda, Aquaculture 


\section{$\underline{\text { Introduction }}$}

An association between intersexuality in Crustacea and anthropogenic disturbance has been reported recently in a number of studies (Moore and Stevenson, 1991, 1994;

Takahashi et al., 2000; Allen et al., 2002; Brian, 2005; EDIT 2003; Ford et al., 2004a, 2005). Intersexuality in wildlife has received considerable attention over the past 15 years due to the links between anthropogenic chemicals and reproductive disorders thought to occur via disruption to endocrine systems (Colburn et al., 1996; IEH, 1999). Recently we reported higher incidences of intersexuality in the marine/estuarine amphipod Echinogammarus marinus from industrially contaminated sites $(\approx 14-15 \%$ intersex $)$ in the Firth of Forth, Scotland, when compared with reference sites $(\approx 5-8 \%$ intersex; Ford et al., 2004a). However, results from an additional study have indicated feminising microsporidian parasites as the most probable cause of the observed intersex (Ford et al., 2006). It was hypothesised that conditions at the impacted sites might have enhanced either parasite numbers, or possibly the ability of the parasites to infect immuno-suppressed hosts, thereby causing an indirect form of endocrine disruption.

Results from that study also indicated that parasitism might not be the only cause of intersex in E. marinus and that other mechanisms may exist, perhaps linked to environmental sex determination, as suggested by Dunn et al. (1993). Despite evidence that parasitism is likely to be the main cause of the intersex observed in $E$. marinus at their polluted site, Ford et al. (2006) suggested that chemicals may also have indirectly contributed to the observations. 


\section{ACCEPTED MANUSCRIPT}

Fjordic sea lochs are characteristic features of the west coast of Scotland. They typically exhibit restricted circulation and accumulate fine grained sediment with high organic carbon content. Many fish farms are located in sealochs. Sediments around farms are often enriched by particulate waste (e.g. faeces, excess feed) from the farms, while dissolved substances may require a period of several days to be flushed out of the loch. The annual Scottish production of farmed finfish (primarily Atlantic salmon) in coastal aquaculture increased from 10,337 to 145,609 tonnes between 1990 and 2003 (FRS, 2002; Read and Fernandes, 2003). This rapid increase in the size of the aquaculture industry has led to concerns over the impact of fish farming on (previously pristine) marine environments (McCaig et al., 1999). The potential impacts are wide-ranging, from aesthetic aspects to direct pollution problems (O’Sullivan, 1992; Garrett et al., 1997). Various effluents are generated by fish farming activities including nutrients, waste feed and faeces, used medications and pesticides, detergents and other effluents from net washing, including antifouling compounds and heavy metals (Read and Fernandes, 2003). Many of these can have undesirable impacts on the environment (Gowen and Bradbury, 1987; Ackefors and Enell, 1994; Wu, 1995; Axler et al., 1996; Kelly et al., 1996).

The chemicals used in European marine aquaculture can be categorised as disinfectants, antifoulants, and veterinary medicines. The medicines used include antibiotics, anaesthetics, ectoparasiticides, endoparasiticides and vaccines (Costello et al., 2001). In Atlantic salmon farming, medicines are predominately used to combat sea-lice, which are the most common and economically significant parasite (Costello et al., 2001). Most of the medicines that have been used have neurotoxic properties towards crustaceans (Davies et al., 2001). 
The endocrine system of crustaceans is closely associated with the nervous system, and consists of epithelial-type endocrine glands and endocrine structures of neural origin, the neurosecretory cells and neurohemal organs (Fingerman, 1995). The neurohormones exert short-term (e.g. pigment concentration and dispersal), mediumterm (e.g. carbohydrate metabolism) and long-term regulatory actions (e.g. regulation of moulting and gonadal development) on the neuro-endocrine systems of crustaceans (De Kleijn and Van Herp, 1995). A clear-cut distinction therefore cannot be made between the nervous and endocrine coordinating systems in Crustacea (Waterman, 1961). Furthermore, the action of crustacean neurons cannot be thought of solely in electrical terms (Waterman, 1961), with components of neuro-endocrine systems found throughout the central nervous system (De Kleijn and Van Herp, 1995). It was therefore hypothesised that chemicals, designed specifically to have neurotoxic effects on parasitic Crustacea, may also have endocrine mediated effects on non-target crustacean at sublethal concentrations.

With this in mind, populations of Echinogammarus marinus were studied in two sealochs (Loch Sunart and Loch Duich) on the west of Scotland containing fish farm sites during 2002 and 2003 (Fig. 1,2). The aim of the investigation was to assess whether waste discharges from fish farms may have any measurable adverse effects on E. marinus populations. The endpoints measured included sex ratios, prevalence of intersexuality and morphology (i.e. parameters potentially indicative of endocrine disruption). The role of microsporidian parasites in structuring E. marinus populations and causing developmental abnormalities was also investigated through histological examination of internal viscera. 


\section{Materials and Methods}

\section{Specimen collection}

Echinogammarus marinus (immature and adult) were collected from underneath stones and seaweeds from Loch Sunart (May and August 2002) and Loch Duich (May 2003). In May 2002, approximately 200-300 E. marinus were collected from each of two sites, one adjacent to a fish farm (Laudale) on the south side at the head of Loch Sunart, and one site (Rubha nam Faennag) on the north side of the loch approximately $2 \mathrm{~km}$ west of the fish farm (Fig. 1). During August 2002, further sampling was undertaken at Loch Sunart, this time at $200 \mathrm{~m}$ intervals along a transect for $800 \mathrm{~m}$ in a westerly direction from the site adjacent to the fish farm. The sample sites at $400 \mathrm{~m}$ and $600 \mathrm{~m}$ were subsequently pooled due to low numbers of specimens collected. In May 2002, the Laudale fish farm at Loch Sunart was holding 2 year old Atlantic Salmon of approximately $1.9 \mathrm{~kg}$ per fish, increasing to approximately $3.1 \mathrm{~kg}$ per fish by August 2002. Licensed medicines used during 2002 included 7.81 of Excis (the active ingredient of which is cypermethrin) and $175.5 \mathrm{~kg}$ of SLICE (contains emmamectin benzoate, a benzoylphenyl urea).

Loch Duich was sampled during May 2003. Approximately 300 E. marinus were collected from each of six sites. One site was directly adjacent to the fish farm on the south coast and the other four sites were at $800 \mathrm{~m}$ and $1600 \mathrm{~m}$ distant in both easterly and westerly directions (Fig. 2). A further reference site was sampled outside the loch, approximately $15 \mathrm{~km}$ from any fish farm activities. In May 2003, the fish farm within Loch Duich contained small first year smolts of approximately $100 \mathrm{~g}$. Medicines 


\section{ACCEPTED MANUSCRIPT}

licensed for use in 2003 included approximately 281 of Excis, although the majority was used after the period when amphipod sampling had taken place.

Samples were preserved in $70 \%$ industrial methylated spirit (IMS) plus $5 \%$ glycerol, and were returned to the laboratory for positive identification. The sexual phenotype was recorded and the specimens were weighed. If specimens were intersexed, the phenotype of intersex was recorded as either intersex male or intersex female, as described by Ford et al. (2003). Proportions of sexual phenotypes were analysed statistically using chi-square tests (SPSS 11.0).

Sub-samples of 300 normal males and females (50 per site from all six sites in Loch Duich), and 34 intersex males and 126 intersex females (pooled from all sites) from Loch Duich were also analysed morphometrically (methods by Ford et al., 2004a), using a dissecting microscope and eyepiece graticule. The measurements taken included weight (mg; normalised by square root transformation), and the lengths of both the left and right sides of gnathopod 1, gnathopod 2, and the eye. These measurements were analysed using canonical discriminant analysis using SPSS 11.0.

\section{Assessment of Microsporidian Infection}

Sub-samples from Loch Sunart $(\mathrm{N}=69$, collected during May 2002) and Loch Duich $(\mathrm{N}=170)$ were further processed histologically. Normal and intersex E. marinus specimens were preserved in ethanol from Laudale Fish Farm (Loch Sunart). Unfortunately, specimens from Rubha nam Faennag, a site $2 \mathrm{~km}$ away from the fish farm site, were not adequately preserved and inter-site comparison could not be made within the loch. Sub-samples (between 10-20) of each sexual phenotype were 
processed for histology from the site $1600 \mathrm{~m}$ east of the fish farm within Loch Duich, and the reference site outside the loch. A further 10 normal female specimens were processed for histology from all other sample sites in Loch Duich. Mid-sections of each specimen were cut transversely using a razor blade between pereon 3 and 4, and wax embedded. Approximately four $5 \mu \mathrm{m}$ sections were cut and stained with Haematoxylin and Eosin (H\&E) and then examined using a high power Olympus BH2 microscope for the presence of microsporidian spores within the musculature and gonadal tissue. Proportions of infection were statistically analysed using G-Tests or Fishers exact tests in cases whereby sample sizes were very unevenly distributed.

\section{$\underline{\text { Results }}$}

\section{Sex Ratios}

\section{Loch Sunart}

Significant differences were observed in the sexual phenotypes between the two sites

(Chi-Square $\chi^{2}=57.89, \mathrm{df}=3, \mathrm{p}<0.001$ ), with the site adjacent to the fish farm (Laudale) characterised by fewer males (27\% of total sample) and more intersex females $(16 \%)$ and the site approximately $2.5 \mathrm{~km}$ from the fish farm characterised by greater numbers of males (47\%) and fewer intersex females (no intersex females observed) than correspondent $\chi^{2}$-expected values (Fig. 3; Table 1). At the fish farm site, $23.1 \%$ of the females and $11.1 \%$ of the males were intersexed, whereas at the other site, there were no intersex females and $6.3 \%$ of the males were intersexed (Table 1).

During August 2002, the proportions of normal and intersex females had declined and normal males were the predominant phenotype (Fig. 4; Table 2). However, results 


\section{ACCEPTED MANUSCRIPT}

from Chi-square analysis revealed no significant differences (Chi-Square $\chi^{2}=13.26$, df $=9, p=0.151)$ in the sexual phenotypes between any of the stations. Although higher proportions of intersex specimens (per total sampled and per female) were observed at the site closest to the fish farm, and numbers of intersex females tended to decrease with distance from the fish farm, the differences were not statistically significant (Table 2).

Table 1: Numbers (Percentages) of each sexual phenotype sampled at Loch Sunart during May 2002.

\begin{tabular}{|c|c|c|c|c|c|c|c|}
\hline Sites & $\begin{array}{c}\text { Intersex } \\
\text { Male }\end{array}$ & $\begin{array}{c}\text { Normal } \\
\text { Male }\end{array}$ & $\begin{array}{c}\text { Intersex } \\
\text { Female }\end{array}$ & $\begin{array}{l}\text { Normal } \\
\text { Female }\end{array}$ & Total & $\begin{array}{c}\% \text { of males } \\
\text { intersexed }\end{array}$ & $\begin{array}{c}\% \text { of females } \\
\text { intersexed }\end{array}$ \\
\hline & $\mathrm{n}(\%)$ & $\mathrm{n}(\%)$ & $\mathrm{n}(\%)$ & $\mathrm{n}(\%)$ & $\mathrm{N}$ & $\%$ & $\%$ \\
\hline Fish Farm (Laudale) & $7(3.4)$ & $56(27.2)$ & $33(16)$ & $110(42.3)$ & 206 & 11.1 & 23.1 \\
\hline Rubha nam Feannag & $9(3.2)$ & $133(47.3)$ & $0(0)$ & $139(49.5)$ & 281 & 6.3 & 0 \\
\hline TOTAL & 16 & 189 & 33 & 149 & 487 & - & - \\
\hline
\end{tabular}

Table 2: Numbers (Percentages) of each sexual phenotype sampled at Loch Sunart during August 2002.

\begin{tabular}{cccccccc}
\hline Sites & $\begin{array}{c}\text { Intersex } \\
\text { Male }\end{array}$ & $\begin{array}{c}\text { Normal } \\
\text { Male }\end{array}$ & $\begin{array}{c}\text { Intersex } \\
\text { Female }\end{array}$ & $\begin{array}{c}\text { Normal } \\
\text { Female }\end{array}$ & Total & $\begin{array}{c}\% \text { of } \\
\text { males } \\
\text { intersexed intersexed }\end{array}$ & $\begin{array}{c}\% \text { of } \\
\text { females }\end{array}$ \\
\hline Fish Farm (0m) & $6(3.9)$ & $95(62.5)$ & $5(3.3)$ & $46(30.3)$ & 152 & 5.9 & $\%$ \\
$200 \mathrm{~m}$ & $0(0)$ & $92(63.9)$ & $5(3.5)$ & $47(32.6)$ & 144 & 0 & 9.6 \\
$400-600 \mathrm{~m}$ & $2(1.6)$ & $66(54.1)$ & $4(3.3)$ & $50(41.0)$ & 122 & 2.9 & 7.4 \\
$800 \mathrm{~m}$ & $3(3.7)$ & $54(65.9)$ & $0(0)$ & $25(30.5)$ & 82 & 5.3 & 0 \\
Total & 11 & 307 & 14 & 168 & 500 & - & - \\
\hline
\end{tabular}




\section{Loch Duich}

Of the 1686 specimens of E. marinus collected during May 2003, $43 \%$ were male, 46 $\%$ female, $2 \%$ intersex male and $9 \%$ intersex female (Table 3). Significant differences were observed in the proportions of sexual phenotypes between sample sites (Chi-Square $\chi^{2}=57.90, \mathrm{df}=15, \mathrm{p}<0.001$, Fig. 5). Stations west of (and inclusive of) the fish farm had fewer intersex specimens than statistically expected, whilst sites east of the fish farm had greater numbers of intersex individuals than statistically expected. The reference site had the lowest percentage intersex specimens $(0.3 \%$ intersex males and $4.4 \%$ intersex females), whilst the site $1600 \mathrm{~m}$ east of the farm had the highest percentage intersex specimens $(4.7 \%$ intersex males and $15.4 \%$ intersex females). Furthermore, the 5 sites within the loch (pooled) showed significant differences in the phenotypes compared to the reference (Chi-Square $\chi^{2}=15.11, \mathrm{df}=3$, $\mathrm{p}<0.01)$. When comparing the numbers of intersex phenotypes per their respective sex, intersex males appeared to increase with distance in an easterly direction, whilst intersex females, with the exception of the reference site, were lower in number at the site closest to the fish farm but increased in number at stations $800 \mathrm{~m}$ and $1600 \mathrm{~m}$ in an east and west direction when compared with the site adjacent to the farm (Table 3). 


\section{ACCEPTED MANUSCRIPT}

Table 3: Numbers (Percentages) of each sexual phenotype sampled at Loch Duich during May 2003.

\begin{tabular}{lccccccc}
\hline \multicolumn{1}{c}{ Sites } & $\begin{array}{c}\text { Intersex } \\
\text { Male }\end{array}$ & $\begin{array}{c}\text { Normal } \\
\text { Male }\end{array}$ & $\begin{array}{c}\text { Intersex } \\
\text { Female }\end{array}$ & $\begin{array}{c}\text { Normal } \\
\text { Female }\end{array}$ & Total & $\begin{array}{c}\text { \% of males } \\
\text { intersexed }\end{array}$ & $\begin{array}{c}\text { \% of females } \\
\text { intersexed }\end{array}$ \\
\hline & $\mathrm{n}(\%)$ & $\mathrm{n}(\%)$ & $\mathrm{n}(\%)$ & $\mathrm{n}(\%)$ & $\mathrm{N}$ & $\%$ & $\%$ \\
Reference & $1(0.3)$ & $134(45.1)$ & $13(4.4)$ & $149(50.2)$ & 297 & 0.7 & 8.0 \\
1600m West & $2(1.0)$ & $85(42.5)$ & $21(10.5)$ & $92(46.0)$ & 200 & 2.3 & 18.6 \\
800m West & $4(1.3)$ & $127(42.6)$ & $22(7.4)$ & $145(48.7)$ & 298 & 3.1 & 13.2 \\
Fish Farm & $4(1.4)$ & $152(51.5)$ & $16(5.4)$ & $123(41.7)$ & 295 & 2.6 & 11.5 \\
800m East & $11(3.7)$ & $115(38.6)$ & $30(10.1)$ & $142(47.7)$ & 298 & 8.7 & 17.4 \\
1600m East & $14(4.7)$ & $113(37.9)$ & $46(15.4)$ & $125(41.9)$ & 298 & 11.0 & 26.9 \\
Total & 36 & 726 & 148 & 776 & 1686 & - & - \\
\hline
\end{tabular}

\section{Morphometric Analyses of Loch Duich specimens}

Morphometric analysis of specimens was conducted to assess differences between sexual phenotypes and sample sites. Canonical discriminant analysis (Fig. 6) separated approximately $72 \%$ of the sexual phenotypes correctly into their appropriate groups. Significant differences were observed between functions 1 to 3 (Wilks-Lambda, $\mathrm{p}<0.001$ ), but not between function 2 to 3 and 3 ( $\mathrm{p}>0.05$ ). The first function accounts for $99.9 \%$ of the total variation; with all four gnathopod measurements (gnathopods 1 and 2, left and right) showing the strongest correlation with this discriminating function. Intersex males formed an intermediate group, based upon gnathopod size, between normal males with larger gnathopods, and normal and intersex females with smaller gnathopods. Intersex males and females showed minimal overlap, since intersex males were not grouped with intersex females and only $4 \%$ intersex females were grouped with intersex males. 


\section{ACCEPTED MANUSCRIPT}

Due to lack of discrimination between normal and intersex females, only male phenotypes were considered for inter-site variation in morphometrics (Fig. 7). The first six discriminant functions were used in the analysis with significant differences between the first four functions (Wilks-Lambda, $\chi^{2}=327.89,76.20,40.73$ and 21.96 for function 1-6 (p<0.001), 2-6 (p<0.001), 3-6 (p<0.01) and 4-6 $(\mathrm{p}<0.05)$, respectively). The first four functions explain approximately $98 \%$ of the total variation $(82.8 \%$ followed by $8.2 \%, 4.2 \%$ and $3.1 \%$ explained by the first four functions, respectively). When comparing morphometric characters of the males, two main groups can be discriminated within the first function. Intersex males form one grouping and all normal males regardless of site form the other group. Similar to the first analysis, all gnathopod measurements make up the highest discriminant scores in the first function separating the two groups (intersexes from normals).

\section{Microsporidian Infection}

\section{Loch Sunart (Laudale Fish Farm)}

Significant differences were observed in the numbers of infected specimens between sexual phenotypes (G-test, $\mathrm{G}=48.4$, $\mathrm{df}=3, \mathrm{p}<0.001$ ). Normal specimens (male and female) had lower numbers of infections than correspondent (Chi Square $\chi^{2}$ ) expected values, whilst greater numbers of intersex specimens (male and female) were infected than expected. All (100\%) intersex male and $95 \%$ (19/20) of intersex female specimens had microsporidian spores present within the musculature. In contrast, only10\% (2/20) and $35 \%$ (7/20) of normal males and females, respectively, were infected. 


\section{Loch Duich}

At $1600 \mathrm{~m}$ east of the fish farm (where the greatest proportions of intersexuality were observed), a significant difference in the frequency of infection was observed between the sexual phenotypes ( $\mathrm{G}$-test, $\mathrm{G}=22.73, \mathrm{df}=3, \mathrm{p}<0.001)$. All intersex males $(10 / 10)$ from this site were found to be infected and $50 \%(5 / 10)$ of the intersex females. Thirty-five percent (7/20) of the normal females were infected, whereas only $10 \%(1 / 10)$ of the normal males were infected. No intersex males were observed at the reference location, and no significant differences were observed when comparing infection in the remaining three phenotypes (Fisher's exact test, $\mathrm{p}>0.05$ ). No infection was observed in normal males and females (0/20) and 20\% (2/10) infection was observed in intersex females.

A further comparison was made between the frequencies of infection in normal females from all sites in Loch Duich. Significant differences were observed in the frequency of infection between sites ( $\mathrm{G}$-test, $\mathrm{G}=18.57$, $\mathrm{df}=5, \mathrm{p}<0.01$ ), with the highest level of infection observed at sites 800 and 1600m east of the fish farm (15\% $(3 / 20)$ and $35 \%$ (7/20) infection, respectively). Sites 800 and $1600 \mathrm{~m}$ west of the fish farm had 5\% (1/20) and 10\% (2/20) infection, respectively. No microsporidian infections were observed in any of the specimens from the site closest to the fish farm $(0 / 20)$, or from the reference site $(0 / 20)$. The percentage of normal females infected correlated significantly and positively with the percentage total intersex specimens observed at all sites (Spearman's Rank Correlation $\mathrm{R}=0.986, \mathrm{p}<0.001$; Fig. 8). 


\section{$\underline{\text { Discussion }}$}

High incidences of intersex and reproductive abnormalities have been reported for several crustacean groups associated with anthropogenic disturbance (Moore and Stevenson, 1991; Takahashi et al., 2000; Allen et al., 2002; EDIT, 2003; Ford et al., 2004a, 2005). In this study, a higher percentage of intersex individuals was observed at Loch Sunart fish farm than at the site away from the fish farm. The incidence of intersexuality varied between 0-16\% intersex females and approximately $3 \%$ intersex males during the earlier sampling period (May 2002), and 0-3.5\% for intersex females and 0-4 \% intersex males during the later sampling period (August 2002). No significant correlation between distance from the fish farm and intersexuality was observed during the second sampling period. It is unclear whether this may have been the result of mixing between amphipod populations. Specimens collected during the later sampling period were considerably smaller (approximately $35 \%$, unpublished data). This lower incidence of intersexuality found later in the year may be due to the association between size and intersexuality (Ford et al., 2003; Ford et al., 2004b). Both Kelly et al. (2004) and Ford et al. (2005) found that the incidence of intersexuality in amphipods varied throughout the year, with higher frequencies of intersex observed during warmer months when more, larger, and mature specimens were present within the population.

A more complex pattern in the incidence of intersexuality emerged from sampling Loch Duich. All sites within the loch had a higher prevalence of intersex individuals when compared to the site outside the loch. However, within the loch, the site closest to the fish farm had the lowest incidence of intersex. Moreover, the incidence of intersexuality was higher in an easterly direction from the fish farm. Sub-surface and 


\section{ACCEPTED MANUSCRIPT}

bottom current data (Scottish Environment Protection Agency, unpublished data) indicate a net residual current moving in a south-easterly direction suggesting potential eastward movement of some discharges from the fish farm.

At Loch Duich, incidences of intersexuality varied between $4-15 \%$ for females and between $0.3-5 \%$ for males. This maximum total incidence of intersexuality (approximately15-20\% in both lochs) is comparable to that observed at impacted sites within the Firth of Forth (Ford et al., 2004a).

Morphometric analysis using characters considered to be sexually dimorphic separated out the four sexual phenotypes into three groups (Fig. 6). One group contained normal males, the other contained both normal and intersex females and the third intermediate group contained intersex males. The degree to which the intersex males and females were discriminated provides strong evidence for treating these two phenotypes separately, as proposed by Ford et al. (2003; 2004b). In similarity with this study, Ford et al. (2004a) found that the discriminating factor between the groups of normal and intersex specimens from the Firth of Forth (Scotland) was gnathopod size.

Ford et al (2004a) found that normal males from an industrially polluted site had reduced gnathopod length, and similar to that observed in intersex males, when compared to normal males. Recognising that the gnathopod length in E. marinus was a secondary sex characteristic and under androgenic gland control (Charnoiux-Cotton and Payen, (1985), the authors suggested that some anti-androgenic, de-masculinising effects might be occurring, caused by contaminants in this area. Discriminant analysis 


\section{ACCEPTED MANUSCRIPT}

of morphometric characters in the current study, however, was not able to differentiate between normal males, at sites near or at distance from the fish farm at Loch Duich, or between sites associated with a high or low incidence of intersex. Intersex males clearly formed at separate group based upon morphology when compared to normal males from all sample sites during the analysis.

Microsporidian parasites were found within the musculature of E. marinus from both lochs in this study. Unfortunately, identification to species level requires molecular techniques which were not then available to the authors. Significantly higher frequencies of infection were observed in intersex specimens than in normal specimens. Infection of normal females correlated with the incidence of intersexuality and, as with previous studies (Ford et al., 2006), very few normal males were infected. This suggests that the parasite is a feminiser and is the probable cause of the observed intersexuality. Strong correlations found between total intersex prevalence and microsporidian infection in normal (non-intersex) females suggest that sampling locations chosen within the Loch Duich study may contain more genetically isolated populations.

Relatively few specimens of any phenotype at the reference sites were infected. Ford et al. (2006) found a higher frequency of intersex organisms throughout the year at two sites associated with industrial discharges when compared to reference sites. Histological examination of those samples found that, as in this study, intersex specimens were more likely than normal specimens to be parasitised by microsporidia. Ford et al. (2006) also found a very low frequency of infection in all sexual phenotypes at two reference sites, adding weight to the suggestions by Dunn et 


\section{ACCEPTED MANUSCRIPT}

al. (1993) and Kelly et al. (2004) that factors other than contamination may cause intersexuality, such as a consequence of environmental sex determination. Sex determination in some species of amphipods is known to be affected by day length; short days producing more females, and long days more males (Naylor et al., 1988). This relative plasticity in sex determination may leave some specimens in an intersex form.

It has been suggested that some parasites might make suitable bioindicators of pollution (Möller, 1987; Khan \& Thulin, 1991; MacKenzie et al., 1995; MacKenzie, 1999). Previously, we proposed that an increase in the prevalence of microsporidian parasites, and the consequential occurrence of intersexuality in E. marinus, might also provide a suitable marker for disturbed environments (Ford et al., 2006). Results from this study corroborate that suggestion, although the interactions of point sources of disturbance (such as fish farms) with the general "disturbance" arising from the restricted circulation and the general enrichment of sea loch environments need to be taken into account. Ford et al. (2004a) suggested that an increased frequency of intersex might have occurred in E. marinus at impacted sites due to immunosupression, and thus a consequent increased parasitic infection. An alternative mechanism by which intersexuality may occur might be through the effects of contaminants on parasite function (Ford et al. 2004a). For example, a contaminant may affect the ability of feminising parasites to change the gender of the host, and consequently lead to incomplete feminisation, and thus resulting in an indirect form of endocrine disruption. In this study, however, relatively low quantities of veterinary medicines were being used at Loch Duich (compared with Loch Sunart) during the time of sampling, and incidence of intersex was low close to the farm, which cast 
some doubt on any direct or indirect role of medicines in causing the observed intersex.

One further explanation for the observed high intersexuality arises, based upon discharges of organic matter to the water. The restricted circulation in sea lochs generally results in a degree of organic enrichment in sea lochs compared to reference sites in more open coastal locations. The area of further organic enrichment of seabed sediments around fish farms is normally confined to a few tens of metres. However, there will be longer distance transport of dissolved organic matter, and also of fine particulate matter which may settle slowly through the water column, or be resuspended periodically from the sea bed. Considering that intersexuality at Loch Duich was more prevalent in the direction of the residual current, organic matter discharged in the form of uneaten fish feed or fecal material, may have created an environment suitable for this particular microsporidian. For example, increased organic input may have led to proliferation of the populations of an alternative host, which, in turn, may have increased infection within E. marinus. This may provide an explanation for the elevated intersexuality observed in E. marinus by Ford et al. (2004a; 2006) at sites impacted by industrially-derived contaminants. Those sites were chosen primarily for the nature of the chemical contaminants present, but also contained elevated organic matter when compared to reference sites (Scottish Environment Protection Agency, unpublished reports). This process has been demonstrated to occur in populations of frogs where malformations associated with parasites, hosted by snail populations, were increased in association with elevated algal food supply, caused by organic pollution (Johnson and Chase, 2004). Whilst some microsporidia are known to possess several hosts covering several different 
phyla, as far as we are aware, multiple hosts covering separate phyla are not currently known within the microsporidians infecting amphipods. The possibility also remains that several of these mechanisms might be occurring at once, and that the balance between them may change with location in the sea lochs studied.

During this study, the site closest to the fish farm at Loch Duich had lower frequencies of intersex than sites either side of the farm, although presumably experienced the highest exposure to organic enrichment and other discharges from the farm. One possible explanation may be that parasiticides or other chemicals used at the farm are affecting non-target parasites (i.e. feminising Microsporidia) within the immediate area surrounding the farm.

In summary, results indicate that a higher incidence of amphipod intersexuality in sites in relative proximity to fish farming activities, however the actual role of fish farms, at this point is not clear. Two phenotypes were observed; intersex male and intersex female. Intersex specimens were significantly more likely to be parasitised than normal specimens, adding weight to earlier suggestions that E. marinus, like several other amphipod species, harbours a feminising microsporidian parasite. The cause of the patterns of intersexuality in sealochs and around fish farms may involve a variety of mechanisms including immunosupression, chemically-mediated altered parasite function and elevated parasite numbers, possibly via alternative hosts. It is unclear what effects this increased intersexuality has on localised E. marinus populations or associated communities. However, it is clear from earlier studies that there are multiple fitness costs associated with intersexuality in amphipods (Ford et al. 2004b). Further research is required to assess the cause of elevated intersexuality in $E$. 
marinus in anthropogenically disturbed environments, and the consequences this may have for local marine communities.

\section{Acknowledgements}

We greatly appreciate the input by Ian Davies and Craig Robinson to this manuscript and the very constructive comments made by 3 anonymous reviewers. 


\section{ACCEPTED MANUSCRIPT}

\section{$\underline{\text { References }}$}

Ackefors, H., Enell, M., 1994. The release of nutrients and organic matter from aquaculture systems in Nordic countries. Journal of Applied Ichthyology, 10, 225241.

Allen, Y., Balaam, J., Bamber, S., Bates, H., Best, G., Bignell, J, Brown, E., Craft, J., Davies, I. M., Depledge, M., Dyer, R., Feist, S., Hurst, M., Hutchinson, T., Jones, G., Jones, M., Katsiadaki, I., Kirby, M., Leah, R., Matthiessen, P., Megginson, C.,

Moffat, C. F., Moore, A., Pirie, D., Robertson, F., Robinson, C. D., Scott, A. P., Simpson, M., Smith, A., Stagg, R. M., Struthers, S., Thain, J., Thomas, K., Tolhurst, L., Waldock, M., Walker, P., 2002. Endocrine Disruption in the Marine Environment (EDMAR). 67pp. Dept. for Environment, Food and Rural Affairs, London, UK. ISBN 0907545165

Axler, R., Larsen, C., Tikkanen, C., McDonald, M., Yokom, S., Aas, P., 1996. Water quality issues associated with aquaculture: a case study in mine pit lakes. Water Environment Research, 68, 995-1011.

Brian, J.V., 2005. Inter-population variability in the reproductive morphology of the shore crab (Carcinus maenas): evidence of endocrine disruption in a marine crustacean? Marine Pollution Bulletin, 50, 410-416.

Charniaux-Cotton, H., Payen, G., 1985. Sexual Differentiation. In: The Biology of Crustacea Bliss, D. E. \& Mantel, L. H. (Eds.). Academic Press, London. 
Colborn, T., Peterson, M.J., Dumanoski, D., 1996. Our Stolen Future.

Little Brown and Co., Boston, 306pp

Costello, M.J., Grant, A., Davies, I.M., Cecchini, S., Papoutsoglou, S., Quigley, D., Saroglia, M., 2001. The control of chemicals used in aquaculture in Europe. Journal of Applied Ichthoylogy, 17, 173-180.

Davies, I.M., Rodger, G.K., Redshaw, J., Stagg, R.M., 2001. Targeted environmental monitoring for the effects of medicines used to treat sea-lice infestation on farmed fish. ICES Journal of Marine Science, 58, 477-485.

De Klein, D.P.V., Van Herp, F., 1995. Molecular biology of neurohormone precursors in the eyestalks of Crustacea. Comparative Biochemistry and Physiology B, 112B, $573-579$.

Dunn, A.M., Adams, J., Smith, J.E., 1993. Is intersexuality a cost of environmental sex determination in Gammarus duebeni? Journal of the Zoological Society of London, 231, 383-389.

EDIT, 2003. Endocrine Disruption in Invertebrates and Top Predators - a programme of research. Newsletter issue 2, October 2003. Department for Environment, Food and Rural Affairs, London. 4pp. 
Fingerman, M., 1995. Endocrine mechanisms in crayfish, with emphasis on reproduction and neurotransmitter regulation of hormone release. American Zoologist, 35, 68-78.

Fisheries Research Services (FRS) 2003. Scottish fish farms annual production survey 2002. Aberdeen, UK: Fisheries Research Services. 53pp.

Ford A.T., Fernandes T.F., Rider S.A., Read P.A., Robinson C.D., Davies I.M., 2003. Reproduction in the amphipod, Echinogammarus marinus: a comparison between normal and intersex specimens. Journal of the Marine Biological Association of the UK, 83, 937-940.

Ford A.T., Fernandes T.F., Rider S.A., Read P.A., Robinson C.D., Davies I.M., 2004a. Endocrine disruption in a marine amphipod? Field observations of intersexuality and de-masculinisation. Marine Environmental Research, 58, 169-173.

Ford A.T., Fernandes T.F., Read P.A., Robinson C.D., Davies I.M., 2004b. The costs of intersexuality: A crustacean perspective. Marine Biology, 145, 951-957.

Ford A.T., Fernandes T.F., Read P.A., Robinson C.D., Davies I.M., 2006. Can pollution cause intersexuality in the amphipod, Echinogammarus marinus? Marine Pollution Bulletin, 53, 100-106. 


\section{ACCEPTED MANUSCRIPT}

Garrett, E., Spencer dos Santos, C.L., Jahncke, M.L., 1997. Public, animal, and environmental health implications of aquaculture. Emerging Infectious Diseases, 3, $453-457$.

Gowen, R., Bradbury, N.B., 1987. The ecological impact of salmonid farming in coastal waters: a review. Oceanography and Marine Biology: an annual review, 25, $563-575$.

IEH, 1999. IEH Assessment on the ecological significance of endocrine disruption: Effects on reproduction function and consequences for natural populations (Assessment A4), Leicester, UK, MRC Institute for Environment and Health.

Johnson, P.T.J., Chase, J.M., 2004. Parasites in the food web: linking amphibian malformations and aquatic eutrophication. Ecology Letters, 7, 521-526.

Kelly, L.A., Stellwagen, J., Bergheim, A., 1996. Waste loadings from a fresh-water Atlantic salmon farm in Scotland. Water Research Bulletin, 32, 1017-1025.

Kelly. A., Hatcher, M., Dunn, A., 2004. Intersexuality in the amphipod Gammarus duebeni results from incomplete feminisation by the vertically transmitted parasitic sex ratio distorter Nosema granulosis. Evolutionary Ecology, 18, 121-132.

Khan, R. A., Thulin, J., 1991. Influence of pollution on parasites of aquatic animals. Advances in Parasitology, 30, 201-238. 
MacKenzie, K., Williams, H. H., Williams, B., McVicar, A. H., Siddal, R., 1995.

Parasites as indicators of water quality and the potential use of helminth transmisssion in marine pollution studies. Advances in Parasitology, 35, 85-144.

MacKenzie, K., 1999. Parasites as pollution indicators in marine ecosytems: a proposed early warning system. Marine Pollution Bulletin, 38, 955-959.

McCaig, A.E., Phillips, C.J., Stephen, J.R., Kowalchuk, G.A., Harvey, S.M., Herbert, R.A., Embley, T.M., Prosser, J.I., 1999. Nitrogen cycling and community structure of proteobacterial $\beta$-subgroup ammonia oxidising bacteria within polluted marine fish farm sediments. Applied Environmental Microbiology, 65, 213-220.

Moore, C.G., Stevenson, J.M., 1991. The occurrence of intersexuality in harpacticoid copepods and its relationship with pollution. Marine Pollution Bulletin, 22, 72-74.

Moore, C.G., Stevenson, J.M., 1994. Intersexuality in benthic harpacticoid copepods in the Firth of Forth, Scotland. Journal of Natural History, 28, 1213-1230.

Möller, H., 1987. Pollution and parasitism in the aquatic environment. International Journal of Parasitology, 17, 353-361.

Naylor, C., Adams, J., Greenwood, P., 1988. Population dynamics and adaptive sexual strategies in a brackish water crustacean, Gammarus duebeni. Journal of Animal Ecology, 57, 2493-2507. 
O’Sullivan, A.J., 1992. Aquaculture and user conflicts. Aquaculture and the environment. Special Publication of the European Aquaculture Society, 16, 405-412.

Read, P., Fernandes, F., 2003. Management of environmental impacts of marine aquaculture in Europe. Aquaculture, 226, 139-163.

Takahashi, T., Araki, A., Nomura, Y., Koga, M., Arizono, K., 2000. The Occurrence of dual-gender imposex in Japanese freshwater crab. Journal of Health Science, 46, $376-379$.

Waterman, T.H., 1961. The physiology of Crustacea Vol. I \& II. Academic Press, New York \& London.

Wu, R.S.S., 1995. The environmental impact of marine fish culture: towards a sustainable future. Marine Pollution Bullutin, 31, 159-166. 


\section{ACCEPTED MANUSCRIPT}

Figures

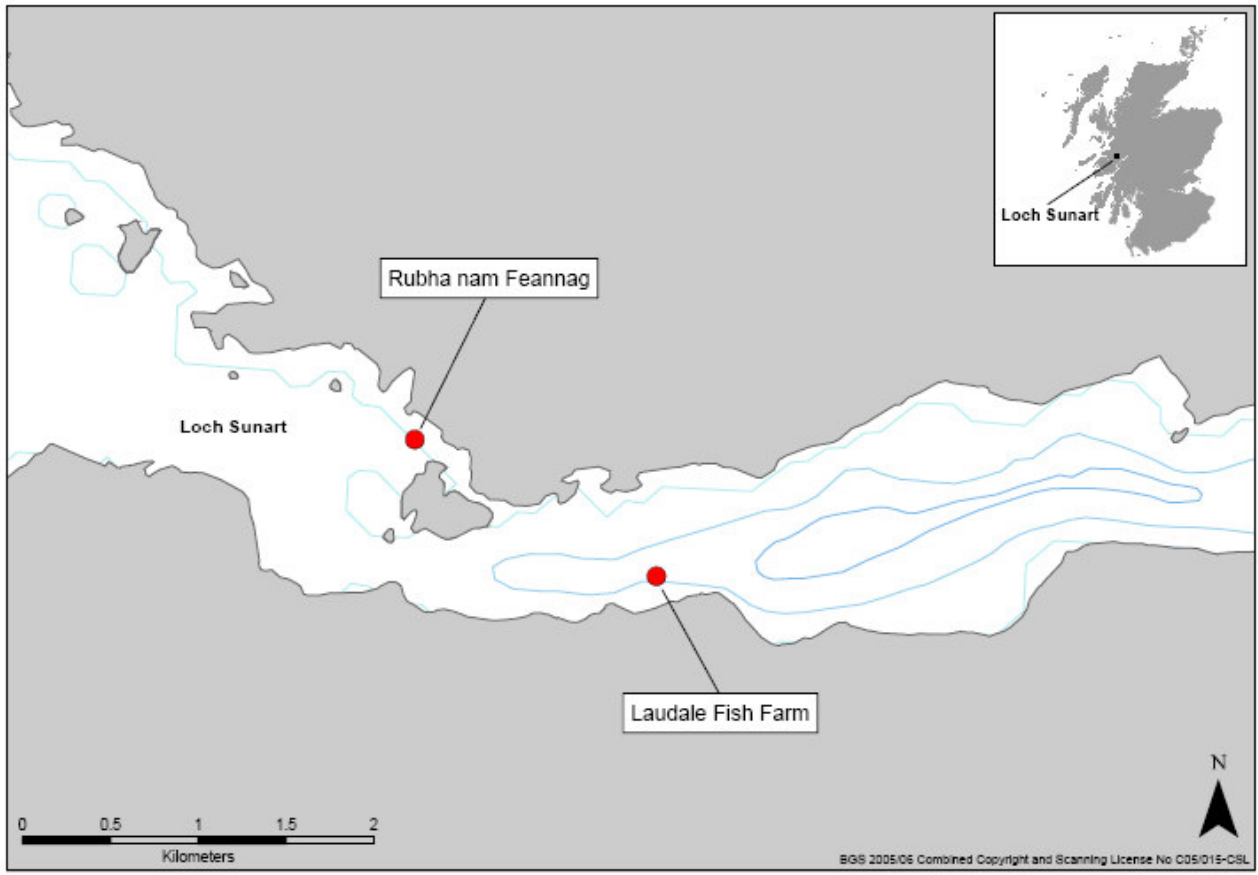

Figure 1: Location of sample sites within Loch Sunart during May 2002

$($ Contours $=20 \mathrm{~m})$.

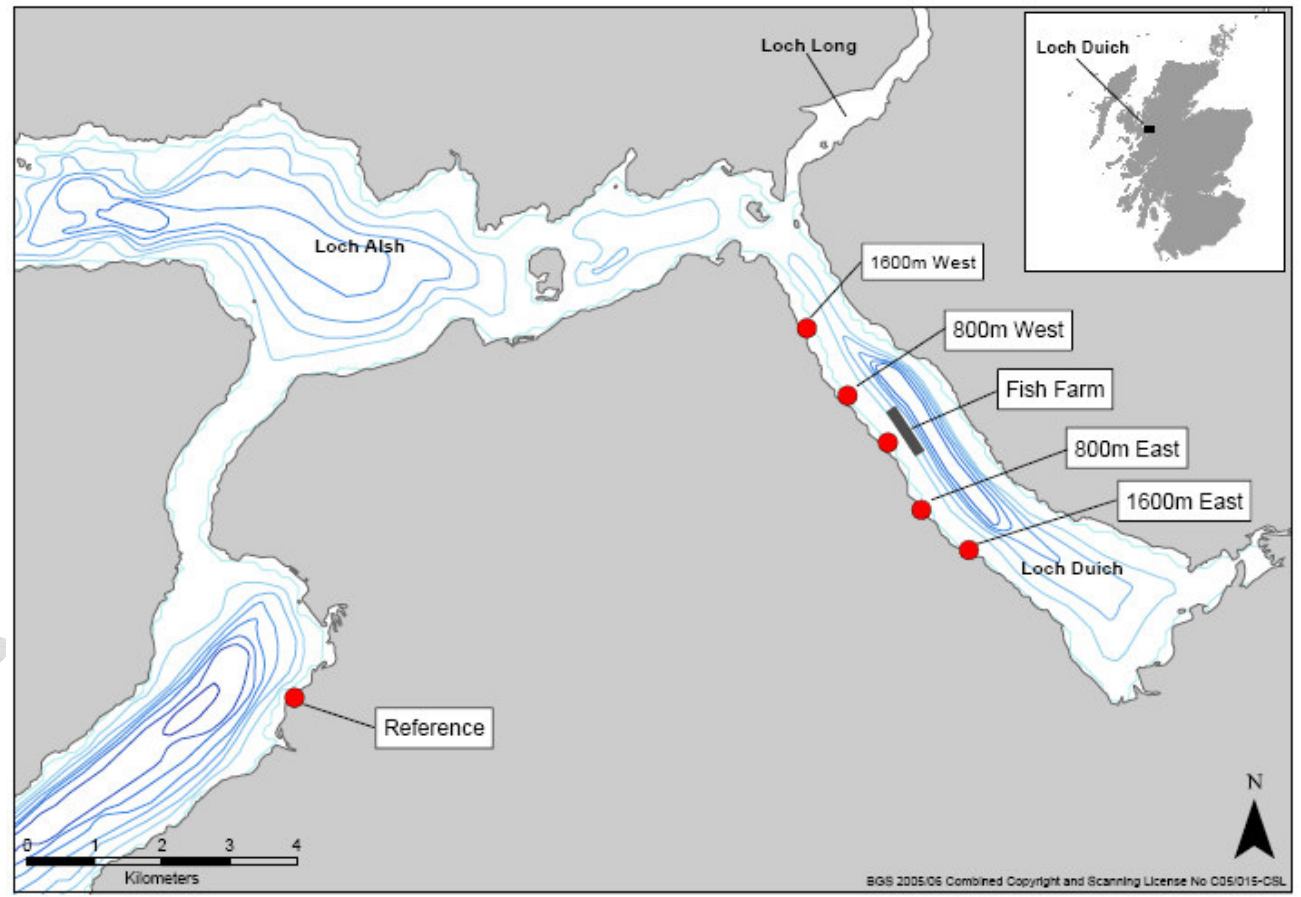

Figure 2: Location of sample sites within Loch Duich during May 2003

$($ Contours $=20 \mathrm{~m})$. 


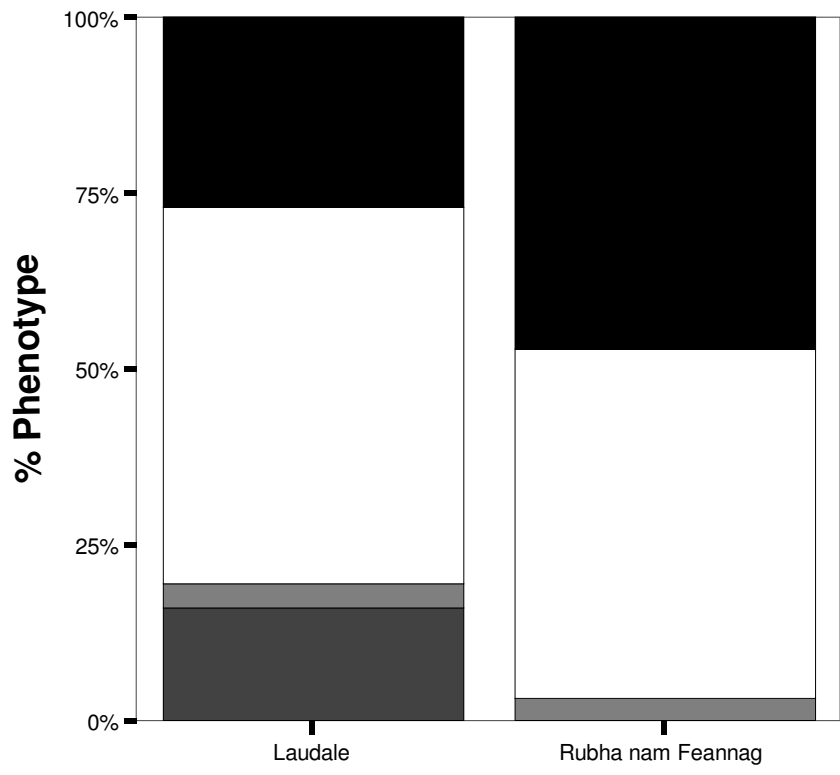

Figure 3: Percentage sexual phenotypes of Echinogammarus marinus collected from Loch Sunart during May 2002. 


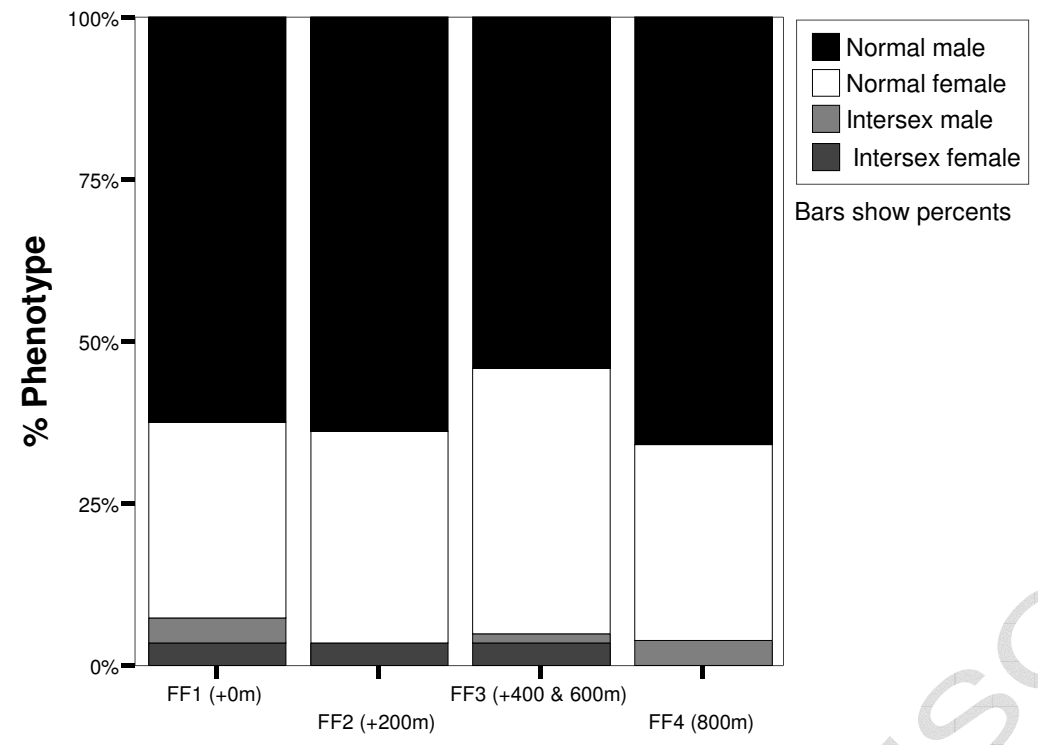

Figure 4: Percentage sexual phenotypes of Echinogammarus marinus collected from Loch Sunart during August 2002.

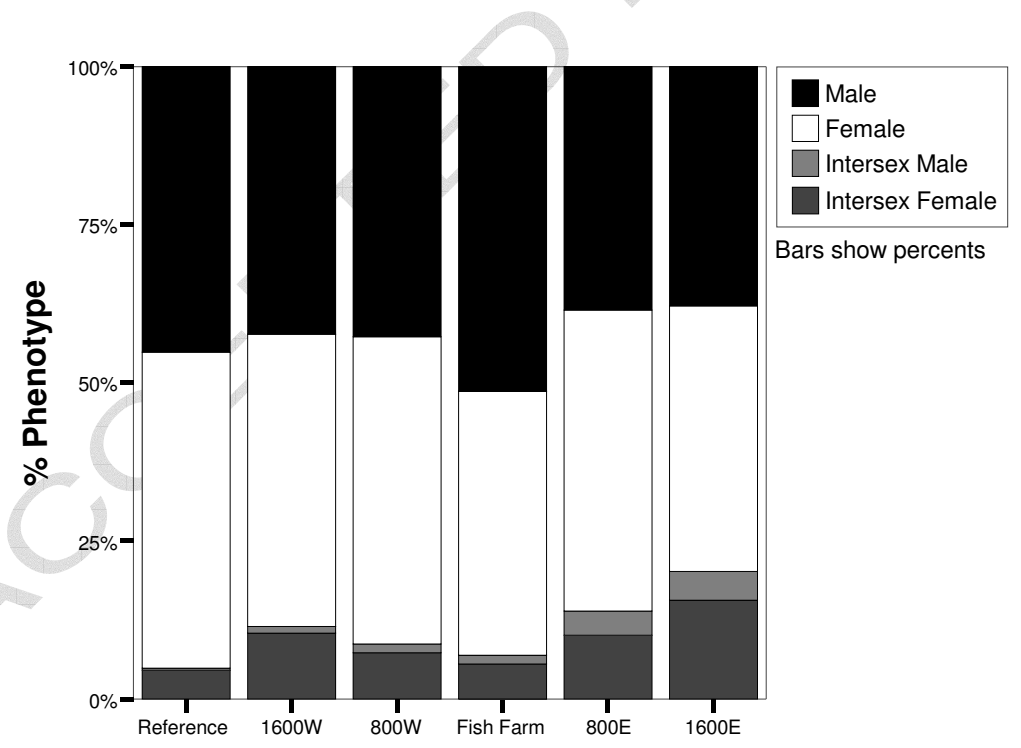

Figure 5: Percentage sexual phenotypes of Echinogammarus marinus collected from Loch Duich during May 2003. 


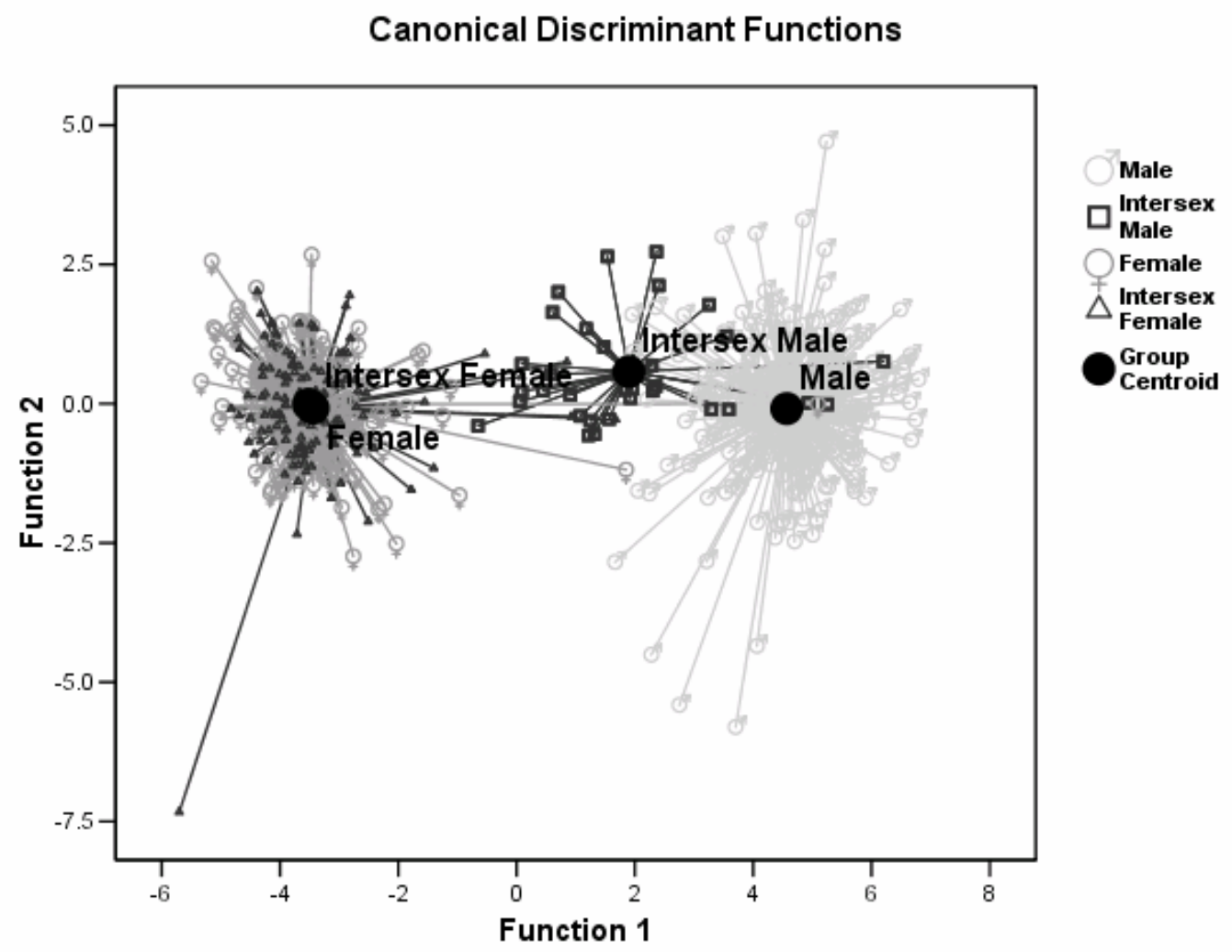

Figure 6: Discriminant analysis of morphometric characters in normal and intersex, male and female Echinogammarus marinus collected from Loch Duich during May 2003. 


\section{Canonical Discriminant Functions}

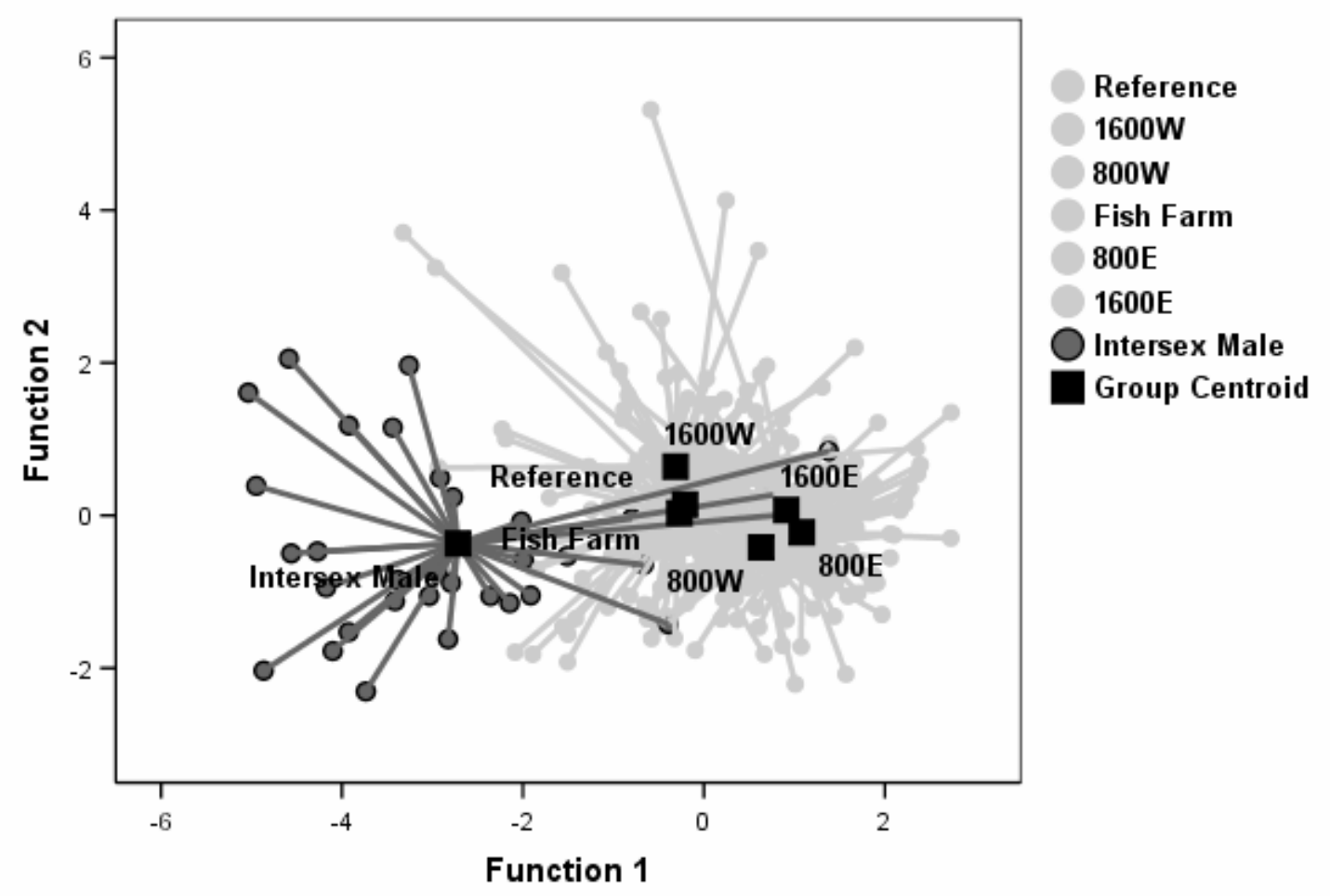

Figure 7: Discriminant analysis of morphometric characters in normal male

Echinogammarus marinus collected from Loch Duich fish farm during May 2003 and compared with intersex male specimens. 


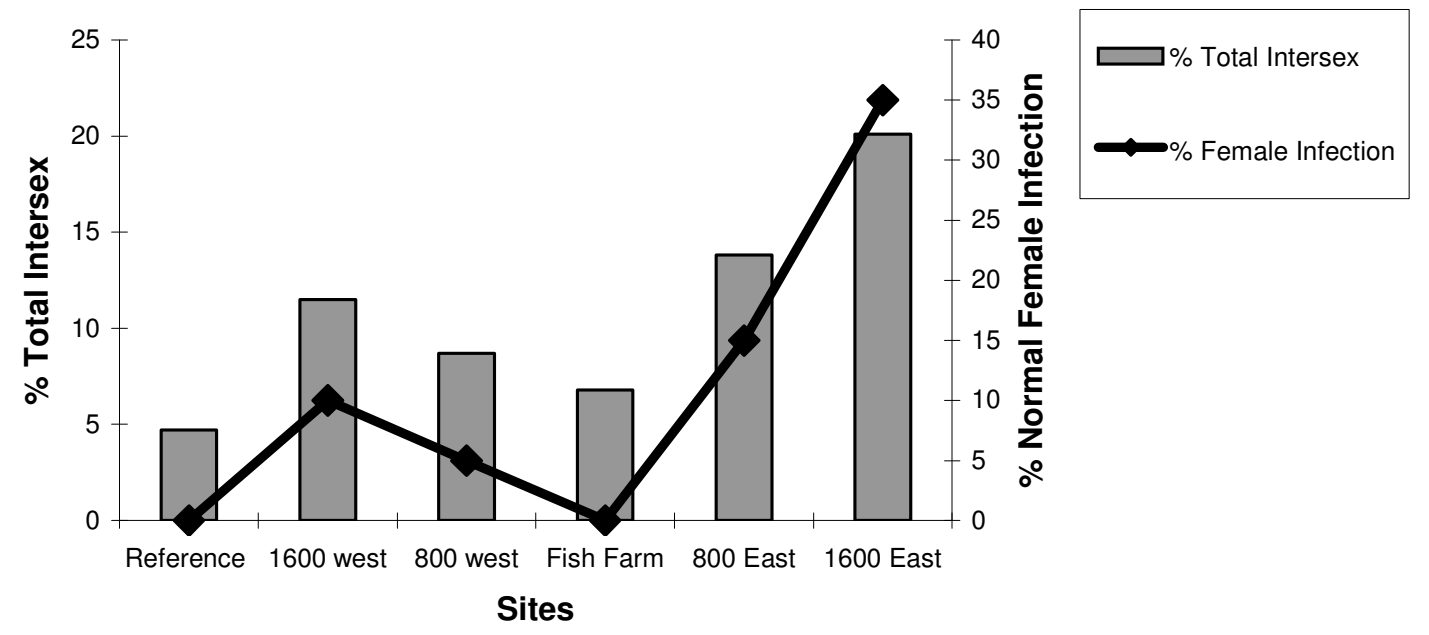

Figure 8: Percentages of total intersex individuals (both males and females) and normal female infection taken from sample sites east and west of the fish farm within Loch Duich, Scotland, and a reference site. 